\title{
Sørnes utgir sin tredje bok om henrettelser
}

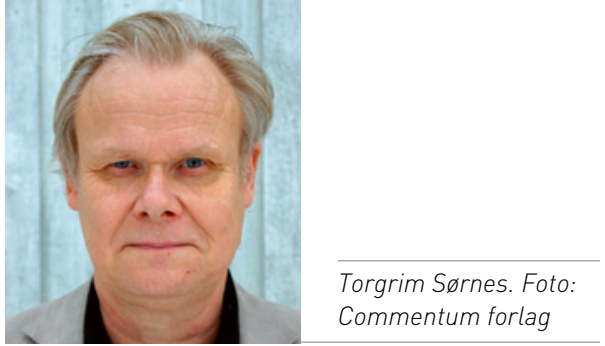

Torgrim Sørnes (f. 1956), gynekolog og overlege ved Fødeavdelingen ved Akershus universitetssykehus, har skrevet tre bøker om dødsstraff og henrettelser i Norge.

Mørkets gjerninger - de henrettede i Norge 1772-1782, utgitt på Commentum forlag, er hans tredje bok, og begge de to forrige bøkene hans om samme tema er tidligere omtalt i Tidsskriftet.

- Dette er bind III i en planlagt serie som skal beskrive alle norske henrettelser mellom 1687 og 1876 . Ideen til en slik serie dukket opp hos meg den dagen jeg oppdaget at Norge ikke hadde noen slik oversikt, ikke en gang i tabellform. Samtidig florerte myter og vandrehistorier både om hvem og hvor mange som var blitt henrettet, for ikke å si hvorfor. Da jeg gikk på skolen, fikk vi høre at det siste mennesket som ble henrettet her i landet, hadde stjålet brød. Det viste seg i og for seg å være sant, han hadde stjålet brød, men våre lærere underslo det faktum at han hadde hugget $\mathrm{i}$ hjel brødets eier med øks først. Det var den slags myter jeg følte at det kunne være viktig å få kastet lys over, forteller Sørnes i et intervju med forlaget.

Mellom 1772 og 1782, perioden som den tredje boken omhandler, ble 31 mennesker henrettet her i landet. Forfatteren forteller hvem de var, og hva de hadde gjort.

Sørnes planlegger flere utgivelser i serien, og i den neste skal han ta for seg perioden 1766-1772.

\section{Gunn Marit Seberg}

Tidsskriftet

\section{En nevø forteller om sin onkels eventyrlige liv}

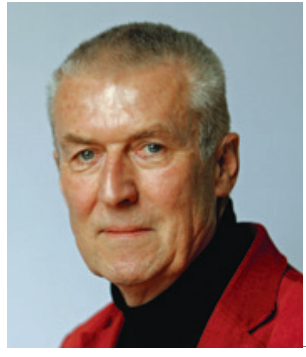

Ole Didrik Lærum

Foto: Det Norske Viden-

skaps-Akademi

Ole Didrik Lærum (f. 1940) har nylig utgitt boken Ingeniøren \& eventyret på Kom forlag. Boken handler om hans onkel - en onkel med samme navn som han selv.

På omslaget beskrives beretningen om sivilingeniøren og professoren Ole Didrik Lærum (1901-1972) som en historie om en begavet norsk ingeniør som i løpet av sin yrkeskarriere satte dype spor etter seg i utlandet og her hjemme: fra byggingen av Flåmsbanen og den transiranske jernbanen til den største transportaksjonen under den annen verdenskrig, via rådgiver for keiseren i Etiopia, til professorat ved Norges tekniske-naturvitenskapelige universitet og den største forsvarsutbyggingen i norsk historie. Deler av arbeidet hans i Norge i etterkrigsårene var hemmeligstemplet forsvarsutbygging, og detaljer om det er først blitt frigitt i senere år.

Legen Ole Didrik Lærum tok medisinsk embetseksamen i Oslo i 1965, doktorgrad i 1969 og ble godkjent spesialist i patologi i 1975. Han har arbeidet innen kreftforskning ved Universitetet i Bergen, i Oslo og ved forskjellige institusjoner i Europa og USA. Siden 2010 har han vært ekstern professor ved Københavns universitet. I tillegg til at han har et rikholdig faglig og vitenskapelig forfatterskap bak seg, har han skrevet en rekke kultur- og helsehistoriske bøker og artikler. Flere av bøkene hans er tidligere anmeldt i Tidsskriftet.

\section{Gunn Marit Seberg}

Tidsskriftet 